\title{
Neonatal Lupus Syndrome: The Heart as a Target of the Immune System*
}

\author{
SIMONE GARCIA and ANTONIO C. CAMPOS-DE-CARVALHO \\ Instituto de Biofísica Carlos Chagas Filho, Universidade Federal do Rio de Janeiro \\ Cidade Universitária, Ilha do Fundão - 21941-900 Rio de Janeiro, RJ, Brasil \\ Manuscript received on December 10, 1999; accepted for publication on December 14, 1999; \\ contributed by A. C. CAMPOS-DE-CARVALHO**
}

\begin{abstract}
Neonatal lupus erythematosus (NLE) is an auto-immune disease related to systemic lupus erythematosus (SLE). Unlike SLE it is not a spontaneous syndrome but rather an acquired one. In NLE the most common disease manifestations are a transient cutaneous lesion and cardiac conduction disturbances. The cutaneous lesions and other non-cardiac manifestations of NLE are transient and disappear about six months after birth, at the time when maternal antibodies disappear from the neonatal circulation. This fact suggests that maternal antibodies may cross the placenta leading to an inflamatory reaction in the fetal tissues. NLE is the principal cause of atria-ventricular block, when it is not associated with congenital birth defects. All the clinical studies to date correlate the heart block in NLE with the presence of certain types of circulating maternal antibodies, against the Ro/SSA nuclear proteins, in the serum of the newborn. In this paper we discuss animal models that have been developed by our and others groups to study the participation of the anti-Ro/SSA antibodies in the pathogenesis of the cardiac conduction blockades that occur in NLE.
\end{abstract}

Key words: neonatal lupus, auto-immunity, heart blockade, anti-Ro/SSA antibodies.

\section{AUTOIMMUNITY}

The primordial function of the immune system in higher organisms is to activate defensive immunological reactions against microbial infections. Cells of the immune system recognize structures and molecular signals that are distinct from the body's own and an immune response ensues. However the immune system must defend the organism without destroying self-constituents and to avoid autoreactions this system has elaborated different mechanisms. First, it has humoral and cellular effector mechanism that specifically recognize foreign

\footnotetext{
*Invited paper

*** Member of the Academia Brasileira de Ciências

Correspondence to: Simone Garcia
}

structural components with minimal cross-reactions to self-antigens. Second, it has supressor mechanisms that inhibit the immunological reactions to self-constituents (Sudhir P 1999). Although the immune system has the properties required to avoid auto-reactions, sometimes the multiple immunological effector mechanisms undergo dysfunction leading to the development of auto-immune diseases.

The initiation of auto-immune diseases in humans can be triggered by different factors: genetic, environmental, immunological, hormonal or infectious. The main genetic factor is the major histocompatibility complex (MHC) which is involved in the maturation of $\mathrm{T}$ cells and in the induction of the immune reaction to protein antigens. Environmen- 
tal and infectious agents are immediate triggers of disease. In the infectious process auto-immunity is not due to the infectious agent itself, but rather to the immune response activated or deregulated by this agent. Hormonal factors may be responsible for the difference in the frequency of autoimmune syndrome occurrence between men and women; for example, the lupus erythematosus syndrome is much more frequent in woman.

The auto-immune process is the result of the loss of balance between the maintenance of immunological defense and the supression of destructive self-reactivity. Most human auto-immune diseases are complex, involving a number of antigens of the target tissue. This may be owed to epitope spreading or to the presence of antibodies to a number of unrelated, organ specific antigens (Rose et al. 1996). Based on adoptive transfer studies in experimental animals there is a strong evidence that T-cell mediated immunity is very important in the pathogenesis of many auto-immune diseases ( Katz et al. 1995), although these studies can not totally exclude the role of antibodies in the development of these syndromes (Rose \& Hill 1996).

The mechanism responsible for the pathogenesis of auto-immune syndromes is the production of a large number of auto-antibodies and auto-reactive $\mathrm{T}$ cells. The auto-immune syndromes can be classified as spontaneous or induced, systemic or organspecific. When an exogenous stimulus triggers the auto-immune process the syndrome is induced, as can be observed in rheumatic fever, a pathological process observed after Streptococcus infection. An example of spontaneous syndrome is lupus erythematosus. In this syndrome and in other connective tissue related diseases there is no evidence for the role of etiologic agents in the development of the disease. The auto-immune diseases classified as organ-specific are characterized by the involvement of only one organ and the auto-antibodies or autoreactive $T$ cells react against organ-specific antigens. Hashimoto's thyroiditis and Diabetes mellitus are examples of organ-specific auto-immune syndromes. In the systemic auto-immune diseases auto-antibodies against antigens spread out throughout the body can be observed, and tissue damage is disseminated. In these systemic syndromes, the auto-immune disfunctions may involve skin, kidneys, joints and muscles.

Systemic lupus erythematosus (SLE) is an example of spontaneous systemic auto-immune syndrome. SLE is the most studied systemic syndrome. It is a inflamatory syndrome which results from an immunologic disturbance that may lead to or be due to the activation of policlonal $\mathrm{B}$ cells, that induce the production of a large number of auto-antibodies. Abnormalities in $\mathrm{T}$ cells and in the antigenpresenting cells have also been observed in patients with disease in activity. Until now it is not clear if the tissue lesions are due to $\mathrm{T}$ cells that infiltrate the organ or to the auto-antibodies in the serum. As mentioned before there is a prevalence of this syndrome in women (10:1 women for man). In SLE there is an involvement of multiple organs (kidneys, heart and nervous system), and cutaneous lesions and joint pain are common. Alterations in cardiac electrogenesis are very rare in adults with LES (Bilazarian et al. 1989) but there is an association between anti-phospholipids antibodies and heart valve disease in SLE (Khamashta et al. 1990). Complete heart block (CHB) is a rare complication of SLE in adults, in contrast to neonatal lupus, in which $\mathrm{CHB}$ is a frequent disease manifestation; no more than 10 cases of CHB in SLE have been reported up to date.

\section{THE NEONATAL LUPUS SYNDROME}

Neonatal lupus erythematosus (NLE) is another auto-immune disease related to SLE. Unlike SLE it is not a spontaneous syndrome but rather an acquired one. In NLE the most common disease manifestations are a transient cutaneous lesion and cardiac conduction disturbances. The cutaneous lesions and other non-cardiac manifestations of NLE are transient and disappear about six months after birth, at the time when maternal antibodies disappear from the neonatal circulation. This fact suggests that maternal antibodies may cross the placenta leading to 
an inflamatory reaction in the fetal tissues. The factors determining whether babies will develop heart block, skin disease, or both, are not yet known.

NLE is the principal cause of total atriaventricular block, when it is not associated with congenital birth defects. Some children may develop a partial or total atria-ventricular block during fetal life or in the neonatal period (Sontheimer \& McCauliffe 1990). In general this manifestation is irreversible, and may be lead to death. All the clinical studies to date show that the heart block in NLE is associated with the presence of certain types of circulating maternal antibodies, against nuclear proteins, in the serum of the newborn. In essentially all cases of NLE associated CHB, auto-antibodies to the Ro/SSA protein complex are present. The Ro particles are ribonucleoproteins which are composed of at least two polypeptides, one with $52 \mathrm{kD}$ and another with $60 \mathrm{kD}$, both of them associated with small RNAs in the nucleus (Mamula et al. 1987, Ben Chetrit et al. 1988). There is no homology between the amino-acid sequences of these two proteins, and they have distinct antigenic regions. Antibodies are directed to the $60-\mathrm{kD}$ Ro/SSA and the 52$\mathrm{kD} \mathrm{Ro} / \mathrm{SSA}$ proteins, although there is a prevalent reaction against the 52- $\mathrm{kD} \mathrm{Ro} / \mathrm{SSA}$ in serological analyses of mothers of children having NLE (Buyon et al. 1993). The $52 \mathrm{kD}$ polypeptide is alternatively spliced, yielding an isoform that lacks aminoacids 169-245 of the full-length protein (Chan et al. 1995). Although their function is not yet known, both the 60 and the $52 \mathrm{kD}$ Ro have zinc finger motifs capable of binding DNA and regulating gene expression (Chan et al. 1991, Itoh et al. 1991). The anti-La/SSB is another auto-antibody found in the serum of mothers and affected children. The La protein is composed by a polypeptide of 47 to 50 $\mathrm{kD}$ (Habets et al. 1983) and is associated to 7S, 5S and tRNAs (Lerner \& Steitz 1979, Rinke \& Steitz 1982, Chambers et al. 1988). The La protein has been described as a transcription termination factor of RNA polymerase III (Gottlieb \& Steitz 1989).

The pathogenesis of CHB in NLE is attributed to an inflammatory process induced by the reactivity of these antibodies with the fetal heart and its conduction system ( Lee et al. 1987). Bear in mind that the antibodies reach the fetal circulation via transplacental transport and that it is the maternal antibodies that react with the fetal tissue. Interestingly, although the mother is the source of the antibodies that induce the clinical manifestations characteristic of NLE, adults with SLE rarely suffer the cardiac conduction blockades seen in NLE. In a well studied case Mevorach et al. (1993) described an adult patient with SLE whose major symptons were $\mathrm{CHB}$ and seizures. The association between those alterations and an auto-antibody mediated mechanism came from the presence of anti-Ro/SSA and anti-La/SSB auto-antibodies in the serum and cerebrospinal fluid of this patient.

Isolated complete heart block occurs in about 1 out of 20.000 births (Michaelsson \& Engle 1972). Many studies have shown that anti-Ro/SSA autoantibodies are the largest single risk factor for the development of CHB in the neonate, in spite of the maternal disease status (Watson et al. 1984). CHB is generally detected between 18-24 weeks of gestation (Buyon et al. 1998), and may be associated with myocarditis. Although anti-Ro/SSA and/or anti$\mathrm{La} / \mathrm{SSB}$ antibodies are present in more than $98 \%$ of the mothers of NLE associated CHB patients, the reported risk of having a child with $\mathrm{CHB}$ for anti-Ro/SSA positive mothers is only 5\% (Smeenk 1997). Meilof et al. (1993) have suggested that the presence of these auto-antibodies are not the only determinant factor to predict the occurrence of CHB. Indeed, the role of anti-Ro/SSA and/or anti-La/SSB in CHB is not clear. It has been suggested that these antibodies react with their corresponding antigens on the surface of the cells of the conduction system in the heart (Horsfall et al. 1991). Although antiRo/SSA antibodies have been eluted from affected fetal cardiac tissue (Reichlin et al. 1994), there is no reason to expect the expression of the Ro/SSA protein, a nucleoprotein, in the surface membrane of the cardiac cells. In that regard it is interesting to note that Miranda et al. (1998) have shown that apoptotic human fetal cardiomyocytes express Ro and La anti- 
gens in the surface. Even though apoptotic cells do not evoke inflamatory reactions the authors speculate that maternal antibody binding to the antigens expressed at the surface of the apoptotic cells might trigger leukocyte migration and cytokine liberation, characterizing a pro-inflamatory response that could affect the healthy cardiomyocytes surrounding the apoptotic ones. Another possibility for the tissue lesions induced by the maternal antibodies is a cross reaction between the auto-antibodies to Ro and $\mathrm{La}$ and a non-related protein expressed on the surface of the cardiac cells. Bellow we present evidence in favor of this hypothesis.

\section{EXPERIMENTAL MODELS FOR NLE}

Researchers have attempted to create experimental models of neonatal lupus in order to study the role of the auto-antibodies in altering cardiac electrogenesis. Based on clinical data that indicate an association between $\mathrm{CHB}$ in neonates and the presence of anti-Ro/SSA antibodies in the serum of the affected babies, Alexander et al. (1992) tested the effect of serum positive for these antibodies in pappilary muscles of rabbit hearts. They demonstrated that superfusion of newborn rabbit ventricular pappilary muscles with IgG-enriched fractions from anti-Ro/SSA positive sera induces a reduction in action potential duration. They further reported that the effect was only present in the $\mathrm{IgG}$ enriched fraction from these sera, that hearts from adult rabbits were unaffected by the anti-Ro/SSA- positive sera, and that sera from lupus patients with other antibody profiles did not alter action potential duration in newborn rabbit hearts.

We showed for the first time that the presence of anti-Ro/SSA or anti-Ro/SSA and anti-La/SSB antibody activity in $\mathrm{IgG}$ fractions from lupus patients' sera can induce cardiac conduction disorders similar to those observed in neonatal lupus (Garcia et al. 1994). Using isolated adult rabbit hearts, we demonstrated that these $\mathrm{IgG}$ fractions induced disturbances in the conduction of the cardiac impulse similar to those observed in neonatal lupus in vivo.
To further characterize the cellular mechanisms involved in the conduction disturbances in the whole hearts, experiments with ventricular myocytes isolated from young rabbit hearts studied by whole cell patch-clamp technique were performed. In these experiments we observed a mean reduction of $32 \%$ in the peak slow inward current, essentially a Ltype calcium current, when the cells were superfused with anti-Ro/SSA positive IgGs. The results in isolated ventricular myocytes correlated well with the observations at the whole heart level, since the conduction in the A-V node is basically dependent on calcium electrogenesis. Our results were later confirmed by Boutjdir et al. (1997) using whole hearts and cardiac myocytes derived from human fetuses.

We also investigated the ability of affinity purified anti-52 kD Ro/SSA antibodies from patients without obstetric history of neonatal lupus to cause heart block in our rabbit heart model (Viana et al. 1998). Affinity purified antibodies were obtained from two sera previously known to induced A-V block by affinity chromatography using a column containing the full-length $52 \mathrm{kD}$ Ro/SSA fusion protein. Paired eluate and effluent, devoid of anti-52 $\mathrm{kD}$ activity, from the same patient were individually perfused in whole hearts. The ability to cause A-V block was restricted to the affinity purified anti-52 $\mathrm{kD}$ eluates. In addition, three affinity purified anti$52 \mathrm{kD}$ eluates from three $\mathrm{IgG}$ fractions that primarily failed to induced cardiac conduction block remained ineffective. The two sera that induced conduction blockade in these experiments were obtained from mothers with healthy infants. In contrast to our rabbit model, Boutjdir et al. (1997) could only see AV conduction block or reduction in calcium currents in the human fetal hearts when using anti-52 kD affinity purified antibodies from mothers who had children with CHB. The reasons for this discrepancy are not immediately obvious, but we speculate that the target protein(s) at the cell membrane may not be $100 \%$ homologous in fetal human and adult rabbit hearts. The challenge now is to unravel the identity of the antigen recognized at the surface of the cardiomyocytes. The obvious candidate, the L-type 
calcium channel, has no sequence homology with the Ro protein.

Curiously, the animal model mentioned above reproduces the variability seen in vivo; i.e., only a small percentage of the $52 \mathrm{kD}$ positive mothers have children with CHB. This is also true for another experimental model now used in the search for the pathological mechanisms underlying the neonatal lupus syndrome; the immunization of mice with recombinant Ro and La proteins. Only a fraction of the pups born from Ro and/or La positive mice exhibited CHB. Actually the first report of CHB in mice to appear in the literature used the monoclonal anti-DNA idiotype 16/6 to immunize Balb/c females (Kalush et al. 1994). The antibody profile in the immunized females was very complex, including antibodies reactive not only to the Ro and La proteins but also to $16 / 6 \mathrm{Id}$, single and double stranded DNA, Sm, RNP and cardiolipin, making the interpretation of the results very difficult. Immunization of Balb/c females with recombinant $\mathrm{La}, 60 \mathrm{kD}$ Ro and the two isoforms of the $52 \mathrm{kD} \mathrm{Ro}$, also resulted in various degrees of $\mathrm{AV}$ conduction blockade in the pups (Miranda et al. 1998). Unfortunately, even in this case, antibody production is not restricted to the injected recombinant protein, since auto-antigen spreading seems to be a rather common finding with these proteins (Deshmukh et al. 1999, Farris et al. 1999, Mason et al. 1999). Nonetheless, the occurrence of CHB in animal models renders this syndrome much more amenable to study, and we anticipate that major progress in unraveling the physiopathology of this disease will be achieved in forecoming years.

\section{ACKNOWLEDGMENTS}

This work was supported by grants from the National Research Council (CNPq), CAPES, FINEP, FAPERJ, The March of Dimes for Birth Defects and FUJB.
Alexander E, Buyon JP, Provost TT \& Guarnieri T 1992. Anti-Ro/SS-A antibodies in the pathophysiology of congenital heart block in neonatal lupus syndrome, an experimental model. Arthritis and Rheum 35: $176-189$.

Ben-Chetrit E, Chan EKL, Sullivan KF \& Tan EM 1988. A $52 \mathrm{kDa}$ protein is a novel component of the SS-A/Ro antigenis particle. J Exp Med 167: 15601571.

Bilazarian SD, Taylor AJ, Brezinski D, Hochberg MC, Guarnieri T \& Provost TT 1989. High-grade atrioventricular heart block in an adult with systemic lupus erythematosus: the association of nuclear RNP (U1 RNP) antibodies, a case report, and review of the literature. Arthritis Rheum 32: 1170-1174.

Boutjdir M, Chen L, Zhang Z, Tseng C, Di Donato F, Rashnaum W, Morris A, El-Sherif N \& Buyon JP 1997. Arrythmogenicity of IgG and anti-52-kD SSA/Ro affinity-purified antibodies from mothers of children with congenital heart block. Circ Res 80: 354-362.

Buyon JP, Winchester RJ, Slade SG, Arnett F, Copel J, Friedman D \& Lockshin MD 1993. Identification of mothers at risk for congenital heart block and other neonatal lupus syndromes in their chidren. Arthritis Rheum 36: 1263-1273.

Buyon JP, Hiebert R, Copel J, Craft J, Friedman D, Katholi M, Lee LA, Provost TT, Reichlin M, Ridder L, Rupel A, Saleeb S, Weston W \& SKovron ML 1998. Autoimmune-associated congenital heart block: demographics, mortality, morbity and recurrence rates obtained from a national neonatal lupus registry. J Am Coll Cardiol 31: 16581666.

Chambers JC, Kenan D, Martins BJ \& Keene JD 1988. Genomic structure and amino acid sequence domains of the human La autoantigen. The Journal of Biological Chemistry 263(34): 18043-18051.

Chan EKL, Hamel JC, Buyon JP \& Tan EM 1991. Molecular definition and sequences motifs of the 52$\mathrm{kD}$ component of human SS-A/Ro autoantigen. $J$ Clin Invest 87: 68-76.

Chan EKL, DiDonato F, Hamel JC, Tseng CE \& 
BUYON JP 1995. 52-kD SS-A/Ro: genomic structure and identification of an alternatively spliced transcript encoding a novel leucinne zipper minus autoantigen expressed in fetal and adult heart. $J$ Exp Med 182: 983-992.

Deshmukh US, lewis, JE, Gaskin F, Kannapell CC, Waters ST, LOU YH, TuNG KS \& Fu SM 1999. Immune responses to Ro60 and its peptides in mice. I. The nature of the immunogen and endogenous autoantigen determine the specificities of the induced autoantibodies. J Exp Med 189(3): 531-540.

Farris AD, Brown L, Reynolds P, Harley JB, James JA, Scofield RH, McCluskey J \& GoRDON TP 1999. Induction of autoimmunity by multivalent immunodominant and subdominant $\mathrm{T}$ cell determinants of La (SS-B). J Immunol 162(5): 3079-3087.

Garcia S, Nascimento JHM, Bonfá E, Levy R, Oliveira SF, Tavares AV \& Campos de Carvalho AC 1994. Cellular Mechanism of the conduction abnormalities induced by serum from anti-Ro/SSApositive patients in rabbit hearts. J Clin Invest 93: 718-724.

Gottlieb E \& Steitz JA 1989. Function of the mammalian La protein: evidence for its action in transcription termination by RNA polymerase. EMBO J 8: $851-861$.

Habets WJ, den Brok JH, Boerbooms AMT, van de Putte LBA \& van Venrroij WJ 1983. Characterization of the SS-B (La) antigen in adenovirusinfected and uninfected Hela cells. EMBO J 2(10): 1625-1631.

Herbert WJ, Wilkinson PC \& Stott DI 1995. The Dictionary of immunology. Academic Press, $4^{\text {th }}$ edition.

Horsfall aC, Venables PJW, Taylor PV \& Maini RN 1991. Ro and La antigens and maternal antiLa idiotype on the surface of myocardial fibres in congenital heart block. J Autoimmunity 4: 165-176.

Iтон K, Iтон Y \& Frank MB 1991. Protein heterogeneity in the human Ro/SSA ribonucleoproteins. The 52 and $60-\mathrm{kD}$ Ro/SSA autoantigen are encoded by separated genes. J Clin Invest 87: 177-186.
Kalush F, Rimon E, Keller A \& Mozes E 1994. Neonatal lupus erythematosus in offspring of mothers with experimental systemic lupus erythematosus. J Clin Immunol 14: 314-322.

Katz SJ, Benoist C \& Mathis D 1995. T helper cell subsets in insulin-dependent diabetes. Science 268: 1185-1188.

Khamashta MA, Cervera R, Asherson RA, Font J, Gil A, Coltart DJ, Vazquez JJ, Pare C, Ingelmo M, Oliver J \& Hughes GRV 1990. Association of antibodies against phospholipids with heart valve disease in systemic lupus erythematosus. The Lancet 335: $1541-1544$.

Lee LA, Coulter S, Erner S \& Chu H 1987. Cardiac immunoglobulin deposition in complete congenital heart block associated with maternal anti-Ro autoantibodies. AM J Med 83: 793-796.

LERner MR \& Steitz JA 1979. Antibodies to small nuclear RNAs complexed with proteins are produced by patients with systemic lupus erythematosus. Proc Natl Acad Sci USA 76(11): 5495-5499.

Mamula MJ, Fox OF, Yamagata H \& Harley JB 1987. The Ro/SSA autoantigen as an immunogen: some anti-Ro/SSA binds IgG. J Exp Med 86: 1889-1901.

Mason LJ, Timothy LM, Isenberg DA \& Kalsi JK 1999. Immunization with a peptide of Sm B/B' results in limited epitope spreading but not autoimmune disease. J Immunol 162(9): 5099-5105.

Meilof JF, Frohn-Mulder IME, Stewart PA, Szatmari A, Hess J \& Veldhoven CHA 1993. Maternal autoantibodies and congenital heart block: no evidence for the existence of a unique heart block associated anti-Ro/SSA auto-antibody profile. Lupus $\mathbf{2}$ : 239-246.

Mevorach D, Raz E, Shalev O, Steiner I \& BenChetrit E 1993. Complete heart block and seizures in an adult with systemic lupus erythematosus. Arthritis and Rheumatism 36(2): 259-262.

Michaelsson M \& Engle MA 1972. Congenital complete heart block: an international study of natural history. Cardiovasc Clin North Am 4: 85-101.

Miranda ME, Chun-E Tseng, Rashbaum W, Ochs RL, 
Casiano CA, DiDonato F, Chan EKL \& Buyon JP 1998. Accassibility of SSA/Ro and SSB/La antigens to maternal autoantibodies in apoptotic human fetal cardiac myocytes. The Journal of Immunology 161: 5061-5069.

Reichlin M, Brucato A, Frank MB \& Maddison PJ 1994. Concentrations of autoantibodies to native $60 \mathrm{kD} \mathrm{Ro/SSA}$ and $52 \mathrm{kD} \mathrm{Ro/SSA}$ in eluates from the heart of a chid who died with congenital heart block. Arthritis Rheum 37: 1698-1703.

Rinke J \& Steitz JA 1982. Precursor molecules of both human $5 \mathrm{~s}$ ribosomal RNA and transfer RNAs are bound by a cellular protein reactive with anti-La lupus antibodies. Cell 29: 149-159

Rose NR \& HILl SL 1996. The pathogenesis of postinfectious myocarditis. Clin Immunol Immunopathol 80: S92-S99.

Rose NR, Skelton FR, Kite JH JR \& Witebsky E 1996. Experimental thyroiditis in the rhesus monkey. III. Course of the disease. Clin Exp Immunol 1: 171-188.
SMEENK RT 1997. Immunological aspects of congenital atrioventricular block. Pace 20: 2093-2097.

Sontheimer RD \& MCCauliffe DP 1990. Pathogenesis of anti-Ro/SSA autoantibody-associated cutaneous lupus erythematosus. Dermatologic Clinics 8(4): 751-758.

SUdHIR P 1999. Autoimmune Reactions. Humana Press, 1999.

Viana VST, Garcia S, Nascimento JHM, Elkon KB, Brot N, Campos de Carvalho AC \& Bonfá E 1998. Induction of in vitro heart block is not restricted to affinity purified anti-52 kDa Ro/SSA antibody from mothers of children with neonatal lupus. Lupus 7: 141-147.

Watson RM, Lane AT, Barnet NK, Bias WB, Arnett FC \& Provost TT 1984. Neonatal lupus syndrome: a clinical, serological and immunogenetic study with revew of literature. Medicine (Baltimore) 63: 362368. 